\title{
Trying to Be All Things to All People: Alternative Development in Afghanistan
}

\author{
David Mansfield
}

\begin{abstract}
Alternative development has had little success in Afghanistan. Understood and implemented as geographically bounded interventions designed to reduce drug crop cultivation, these projects failed to achieve their objectives throughout the 199os. Since 2001, following the fall of the Taliban, unprecedented rises in levels of opium production, and an inflow of substantial amounts of aid, alternative development came to mean different things to different people in Afghanistan. To some, alternative development continued as short-term interventions designed to extract agreements from communities to reduce opium production, or reward those that had already done so. To others, it could be any development programme implemented in a poppy growing, or potential poppy growing, area often without any consideration of the causes of cultivation and how they differed by location, gender or socio-economic group. This chapter argues that a lack of consistency and clarity in approach — and in particular the failure to articulate and implement a strategy to support farmers transitioning to licit livelihoods within a changing framework of development assistance-confined alternative development and efforts to reduce poppy cultivation though rural development to the margins in Afghanistan. To quote Corinthians, in trying 'to be all things to all people', alternative development saved no one.
\end{abstract}

The term alternative development has confused many, perhaps no more so than in Afghanistan (UNODC, 2009). To those specialising in the subject, the

1 About the chapter title: In the King James Bible, Corinthians 9:19-23, Paul talks of 'becoming all things to all people, so that I might by any means save some'.

This chapter draws heavily on work the author did on alternative development in Afghanistan for the Afghanistan Research and Evaluation Unit (2004-19), EastWest Institute (2012-16) and the Special Inspector General for Afghanistan Reconstruction (2014-18).

(C) DAVID MANSFIELD, 2020 | DOI:10.1163/9789004440494_006

This is an open access chapter distributed under the terms of the CC-BY-NC 4.o ligennse. Mansfield - 9789004440494 
intention of alternative development is clear-it is an intervention specifically designed to support rural communities in abandoning drug crop cultivation. Yet to most development practitioners and policymakers outside this narrow clique, alternative development remains an opaque term, defined by its intended outcome-a reduction in opium, coca, or indeed cannabis cultivationwith little guidance as to how this might best be achieved.

Differences between those in the drug control community further confound development policymakers and practitioners working in drug crop-producing areas. For example, some donors, such as the United States Bureau of International Narcotics and Law Enforcement Affairs (INL), and often the United Nations Office on Drugs and Crime (UNODC), press for development assistance to be contingent on reductions in cultivation - a concept known as conditionality — and tied to eradication of the opium crop. Other donors, such as the Deutsche Gesellschaft für Internationale Zusammenarbeit (GIZ) and the European Union (EU), talk of alternative development as inclusive, participatory, pro-poor, and not tied to reductions in cultivation per se, but to improvements in human development indicators. These contrasting approaches can leave many of the main bilateral and multilateral donors asking if alternative development does not differ from other development programmes, why does its implementation lie with specialised institutions such as UNODC, which have a drug control mandate and rather limited development capacity? In addition, recent moves to expand the alternative development concept to include urban communities exposed to crime or drug use have further confused development donors as to what exactly alternative development is.

Afghanistan is one place where this confusion has possibly played out more than most. While some may dismiss the experience of alternative development in Afghanistan as anomalous due to the challenging security environment, the scale and amount of rural development assistance undertaken has been significant, with the United States (US) alone spending USD 1.46 billion on alternative development as part of USD 2.3 billion on agriculture, within a total budget of USD 30.5 billion on governance, economic and social development between 2002 and 2019 (SIGAR, 2019a, 132). While over the last decade some districts have been 'off limits' due to the insurgency, large amounts of development assistance have been delivered in rural Afghanistan, including many areas where poppy is concentrated. Moreover, as the country responsible for the production of almost 9o per cent of the world's illegal opiates, it is hard to argue that the experience of alternative development in Afghanistan is somehow irrelevant.

In fact, the experience in Afghanistan is akin to what has been seen in other illicit drug crop-producing countries, including Colombia, Pakistan and 
Bolivia, with development efforts to curb cultivation veering from short-term, single-sector interventions aimed at coercing farmers to abandon opium poppy cultivation (or rewarding those that have done so already) to large rural development programmes. In Afghanistan, many of these rural development programmes have been referred to or budgeted as alternative development, but given little to no consideration to the causes of opium production and how farmers might respond to the activities pursued, including the risk of increased opium poppy cultivation.

Drawing on extensive documentation, interviews, and the author's direct experience in Afghanistan since the 1990s, this chapter documents the continuing schism between those who see development interventions as a means of extracting an agreement from communities to reduce or abandon opium poppy cultivation in Afghanistan and those who distance themselves from the entire drug economy, despite their responsibility for delivering significant amounts of aid to rural areas, and who at best see a reduction in opium poppy cultivation as an externality of the development process and feel no obligation to ensure that their interventions do not make matters worse.

The chapter is divided into five further sections. Section 2 outlines the methodology —an approach that draws heavily on the author's own experience in-country and direct access to both grey literature and internal policy debates. Section 3 offers a brief history of alternative development in Afghanistan in the 199os - the programmes, the actors and the reasons for its failure. Section 4 examines the period since the collapse of the Taliban regime, as well as efforts to redefine and recast alternative development within the context of significant inflows of development assistance, dominant multilateral and bilateral donors, and sector-based interventions. Section 5 examines why the effort to adopt a more effective strategy, widening the responsibility for addressing the causes and consequences of illicit drug crop cultivation to include international and national development institutions, failed. The final section offers a conclusion.

\section{$2 \quad$ Methodology}

This chapter is a retrospective exploratory inquiry and draws on the author's experience of more than two decades specialising in rural development in poppy growing areas in Afghanistan, and more than 25 years' work on alternative development and research in drug crop growing areas in Afghanistan, and elsewhere. It draws on data from direct observation, largely collected through quasi-participatory techniques; data from secondary sources, including 
evaluation reports, project documents and other grey literature; and research on the ground with those growing opium poppy in Afghanistan for organisations such as the Afghanistan Research and Evaluation Unit (AREU) and the United Nations Drug Control Programme (UNDCP)—now UNODC. ${ }^{2}$

The author's experience in Afghanistan included working for UNDCP's Afghanistan Programme between 1997 and 2001 as a Monitoring and Evaluation Specialist on the Afghanistan Opium Poppy Reduction Project. He then worked for the Government of the United Kingdom (UK) between 2001 and 2014, when it was designated the lead, then partner, nation for counternarcotics under the Security Sector Reform process. Work for, and subsequent reporting to, the UK government, included contracts with the World Bank, EU, Asian Development Bank, GIZ, the governments of the Netherlands and of Canada, the Special Inspector General for Afghan Reconstruction (SIGAR) and a number of non-governmental organisations. These and earlier contracts focused on supporting the integration into rural development programmes of measures that addressed the causes of opium poppy cultivation, as well as the evaluation of interventions in areas where drug crops were concentrated.

This experience provided direct first-hand knowledge of the workings of a number of multilateral, bilateral, national, and non-governmental institutions and how they understood drug crop cultivation and what might be done to address it. Acting as a participant in policy discussions, and both planning and monitoring and evaluation missions, it was possible to document the perceptions of policymakers and practitioners with regard to alternative development, and the extent to which decision makers and implementers believed development and alternative development interventions could be used to meet political, development and drug control objectives. The author was actively involved in these discussions, as well as in the monitoring and evaluation of a range of different programmes, including GIZ's Project for Alternative Livelihoods Program Eastern Afghanistan (PAL), USAID's Alternative Livelihoods Program-East (ALP-East), and its successor Incentives Driving Economic Alternatives-North East West (IDEA-NEW), the World Bank's National Emergency Rural Access Project (NERAP), the UK funded Comprehensive Agricultural and Rural Development -Facility (CARD-F), and the Helmand Food Zone (HFZ).

2 The author's research on poppy cultivation in Afghanistan is extensive. It includes 24 reports on his in-depth research for AREU alone, and more than 75 reports in total. This work includes more than 20,0oo household interviews and fieldwork in a wide range of rural areas, including Helmand, Nangarhar, Kandahar, Farah, Nimroz, Logar, Laghman, Badakhshan, Herat, and Ghor. 
In doing this work, and subsequently leading SIGAR's Lesson Learned project on counter-narcotics - an ex poste evaluation of the US government counter-narcotics effort between 2002 and 2017-the author conducted an extensive review of programme and project documents, which provided a further opportunity to determine the degree to which policies and programmes directly incorporated efforts to curb opium production and/or mitigate the risk that they could result in rising levels of cultivation.

Alternative Development: the Bounded and Failing Interventions of the $1990 \mathrm{~s}$

During the 1980s and throughout much of the early 199os Afghanistan was at war. Following the Soviet Union's retreat in 1989 and the collapse of the Najibullah Government in 1992, the country divided along geographic and political lines, ruled by the different protagonists in what had been the armed opposition to the communist regime - the mujahidin. By the end of 1993, the United Nations (UN) had developed a rehabilitation and humanitarian mission in consultation with these regional leaders. The mission proposed a wide range of interventions aimed at supporting rural communities' efforts to improve their economic position, but also aided an embryonic peace process (UNDCP, 1995b). This was an environment constrained by contested space, the challenges of working with and directing aid through armed groups, and limited funds.

Part of the UN mission in Afghanistan in the 199os included efforts to curb the production, trafficking and use of illicit drugs. In addition, during much of the 1990s there were a number of development interventions implemented in Afghanistan under the label of alternative development, their primary objective being the reduction of opium poppy cultivation. UNODC, and the Narcotics Affairs Section (NAS) of the US Embassy in Islamabad, funded the vast majority of these interventions, which included a wide array of rural development initiatives in poppy growing areas scattered across a large number of districts in Afghanistan. Some interventions took in activities aimed at improving agricultural yields and incomes, and these included irrigation projects. Others involved livestock interventions and the provision of agricultural inputs. Some programmes more resembled all-encompassing, multi-sector programmes that looked to improve the health and education of the local population, as well as local incomes. The only common feature of these alternative development programmes was their specific tie to achieving drug control targets within a given geographic boundary. 
Problems beset each of these projects and programmes: all closed early, and none succeeded in reducing opium poppy cultivation. For example, both UNODC projects - the Afghanistan Drug Control and Rural Rehabilitation Program (ADCRRP), which ran from 1989 to 1996, and its Afghanistan Pilot Program's Poppy Reduction Project (C28), which ran from 1997 to 200o-ended earlier than planned due to a lack of funding. The US government also ceased its support for an alternative development project implemented by Mercy Corps International (1989-99), a US-based non-governmental organisation. This two-year programme called for communities in central Helmand to reduce opium poppy cultivation by 80 per cent in return for crop substitution and the rehabilitation of a canal, but it was closed a year early due to increased opium poppy cultivation (Mansfield, 2001, 7).

A detailed review of these alternative development interventions, particularly ADCRRP and $\mathrm{C} 28$, indicates that each suffered from the same structural weakness: the lack of a coherent and effective strategy for addressing the causes of opium poppy cultivation and, as a consequence, the setting of what were unrealistic goals and time frames. In the absence of a clear strategy as to how interventions might address the multifunctional role that opium played in livelihood strategies, each project adopted a rather crude model, trading development assistance for reductions in opium poppy cultivation. Sometimes this operated directly with the community and its political elite; sometimes in conjunction with local political-military actors; and, in the case of UNODC's $\mathrm{C} 28$, with the Taliban authorities themselves (Mansfield, 2004; 2001).

The time frame within which communities were expected to abandon opium poppy in return for assistance was short (between two and four years); the development assistance was insufficient, geographically dispersed, and failed to take account of both the uneven nature of the development process and the fact that motivations and factors that influenced opium poppy cultivation varied across population groups. The approach was so unrefined that it was often hard to tell the difference between projects funded under the rubric of 'alternative development' and those designed simply to offer respite to a rural population that was experiencing vulnerability due to conflict and poverty.

ADCRRP was an exemplar of such an alternative development intervention. Consisting of over 200 sub-projects implemented by more than 40 different international and national non-governmental organisations ( $\mathrm{NGO} \mathrm{s)}$ ) and with a budget of only USD 9.2 million (UNDCP, 1996, 4), its activities were scattered across multiple districts in the five provinces of Badakhshan, Helmand, Kunar, Nangarhar and Kandahar. There was little hope that ADCRRP could achieve much beyond the delivery of rehabilitation and reconstruction activities in the different funded sectors: agriculture, health, education, income-generation 
and infrastructure. In fact, UNDCP's own assessment concluded, 'It is a disturbing fact that as yet there is insufficient evidence to state positively that the program of alternative development had made any reduction to opium production [...] Projects undertaken in the provinces have been scattered and cannot be linked to any specific reduction' (UNDCP, 1995a, 23-24).

Despite the limited development impact that ADCRRP was expected to achieve, the programme stipulated that communities that received assistance should cease opium poppy cultivation altogether regardless of the activities delivered or who accrued the benefits. It was not apparent how the delivery of the particular sub-projects selected could actually manifest in reducing opium poppy cultivation beyond the requirement that communities sign an agreement to abandon the crop-'a poppy clause' (UNDCP, 1995a, 23-28).

The poppy clause itself was criticised by implementing NGO s (Afghanaid, $1989,22-24)$ as well as UNODC's own review team, which went so far as to suggest it was counterproductive. The signed agreements brought communities, NGO s and the UN into the dispute (UNDCP, 1995a, 24). At the time, some of the NGO s involved in humanitarian work such as demining questioned the ethics of making assistance conditional on reducing poppy cultivation. In some cases, the poppy clause pressed local military commanders to destroy the opium crop of remote rural communities, despite limited evidence of development impact (Afghanaid, 1989, 22-24). In most cases, continued cultivation did not lead to the termination of project activities. In the end, ADCCRP was deemed ineffective in reducing opium poppy cultivation (UNDCP, 1995a, 25). The UK's Department for International Development (DFID) went further, and - unable to discern a clear programme strategy that distinguished ADCRRP from other rural development programmes-questioned the efficacy of funding UNODC to undertake what appeared to be conventional rural development projects (Kapila et al., 1995, 52).

UNODC's follow-up Poppy Reduction Project ( $\mathrm{C} 28)$ offered some improvements on its predecessor, ADCRRP, but ultimately very few. Learning from the experience of ADCRRP and its disparate geographic spread, $\mathrm{C}_{2} 8$ did focus its efforts on four target districts: Shinwar district in Nangarhar in the east, and the districts of Ghorak, Khakrez and Maiwand in the province of Kandahar in southern Afghanistan.

$\mathrm{C} 28$, however, also consisted of more than 200 sub-projects implemented by NGO s, Drug Control and Coordination Units (DCCU s) - which belonged to the Taliban authorities of the time - and the Agricultural Departments of the Universities of Kandahar and Nangarhar. Like ADCRRP, the budget for $\mathrm{C}_{2} 8$ was also insufficient for the task. Of the USD 10.5 million that UNODC received in funds, approximately USD 3 million was spent in the four target districts, as 
well as on a number of provincial-level initiatives aimed at gaining the support of the provincial Taliban authorities (Sloane, 2000, 10).

Like ADCRRP, C28 also committed to dramatic reductions in opium poppy cultivation over a short period. In the case of $\mathrm{C} 28$, opium poppy was to be eliminated in each of the target districts over a four-year period. Future development assistance was contingent on meeting an agreed schedule of reductions, formalised in what became known as Drug Control Action Plans (DCAP s), which were drawn up by UNODC and signed by the Taliban authorities and representatives of local communities.

Multiple reviews of UNODC's Afghanistan programme expressed concerns regarding the ambition of $\mathrm{C} 28$ and the targets that it had set for reducing opium poppy cultivation. The donors raised questions about UnODC's relationship with the Taliban, or, as they were referred to at the time, 'the presumptive authorities'; the capacity-building work the Office was doing with Taliban institutions (UNDCP, 1997, 17); the technical and financial assistance that UNODC provided to the Taliban's efforts to electrify Kandahar (UNDCP, 1997, 17); and the then Executive Director's efforts to launch a ten-year national programme (UNDCP, 1997, 15), which would undoubtedly have led to the channelling of further support to the Taliban (UNDCP, 1997, 15 and 17).

The DCAPs and the 'conditionality' under which $\mathrm{C}_{2} 8$ operated were also subject to criticism. Perceived as inflexible (Mackrell, 1999, 7; Gelbert, 2000, 27; Sloane, 2000, 30), inappropriate for what was meant to be a pilot programme designed 'to develop and implement replicable methodologies for achieving reductions in poppy cultivation in Afghanistan' (UNDCP, 1997), and lacking community ownership, the DCAP s often became little more than fora in which the Taliban, the local authorities and community representatives could request and negotiate assistance. Moreover, despite yearly breaches of elimination schedules, development assistance was not withdrawn (Sloane, 2000, 27). As with ADCRRP, the final Project Impact Report described $\mathrm{C}_{2} 8$ as largely a district wide, village level agricultural development project with little to distinguish it from many other such projects implemented by international agencies and NGO s' (Sloane, 2000, 27).

Based on the level of opium poppy cultivation in 1997, the year in which $\mathrm{C}_{2} 8$ began, Shinwar experienced a 12 per cent reduction in cultivation between 1997 and 2000, Ghorak a 6o per cent reduction, Maiwand a 22 per cent reduction, and Khakrez an 11 per cent increase. According to the revised DCAP s, which used 1998 as the base year, all four districts witnessed a reduction in opium poppy cultivation between 1998 and 2000: 5 per cent in Shinwar, 49 per cent in Ghorak, 6o per cent in Maiwand, and 61 per cent in Khakrez. The final review concluded, however, that the results in the three districts in Kandahar province were attributed to drought and not to the efforts of $\mathrm{C}_{2} 8$ (Sloane, 2000, 3). 
In sum, by the turn of the millennium alternative development had fallen into disrepute in Afghanistan. In the absence of a coherent strategy to address the different reasons why farmers produced opium and the multiple roles that the crop played in livelihood strategies, alternative development became closely associated with crude efforts to encourage those who had gained military power-first local warlords and then the Taliban-to coerce the rural population to abandon opium poppy cultivation. The drug control community, too, favoured this persuade-to-coerce standpoint, rather than seeing development assistance as a means by which to improve the quality of the lives of those cultivating the crop. Devoid of a clear understanding of the multifunctional role of opium production and how to replace it, alternative development largely engaged in horse-trading - making offers of assistance to the local authorities and elites within communities in return for poppy elimination.

In reality, none of those involved in this horse-trading kept their end of the deal. For those delivering the development assistance, the funds received were insufficient and too short-term to deliver the necessary development outcomes required if farmers were to meet their basic needs. Moreover, the benefits that did accrue from development assistance tended to go to the wealthier members of the community, who were the least dependent on opium (Gelbert, 2000, 5; Sloane, 2000, 17). Regarding the rural population, few reduced opium poppy cultivation even where they had signed agreements to refrain from production, arguing that they could not sustain themselves on the limited assistance provided without recourse to opium production.

Finally, those charged with imposing a ban and eradicating the crop were reluctant to compel farmers to abandon the crop if the rural population was not provided with viable alternatives. Indeed, local authorities rarely acted against the crop, aware of the fact that power in rural Afghanistan is negotiated, decentralised and contested. In the absence of a concentration of coercive power, the politico-military leadership in rural Afghanistan remained concerned that marginalising large sections of the rural population, through eradication or imposing a ban on opium poppy, would result in a loss of support, and ultimately of political power (Mansfield, 2016).

\section{4 \\ Alternative Development: Attempts to Redefine, Recast and Widen Ownership}

With the fall of the Taliban in 20o1, the political and economic landscape in Afghanistan changed significantly. Alongside shifts in development thinking, there was a move away from the more small-scale, geographically 
focused alternative development interventions implemented in Afghanistan in the 199os. There was also little appetite for interventions that put drug control at the forefront of international state-building efforts in order to extract reductions in cultivation from Afghan leaders in return for development assistance.

Furthermore, at the turn of the twenty-first century, donors began to prioritise sector-based interventions, with Western nations and multilateral institutions supporting more wide-scale reform across entire areas of government delivery, including health, education, rural development and roads. In Afghanistan, sectoral assistance often took the form of technical support to central ministries in Kabul, as well as funds for the delivery of national development programmes. Much of this assistance was directed through the World Bank, which took the lead in the design and oversight of the National Priority Programs (NPP s) and administered the Afghanistan Reconstruction Trust Fund (ARTF), from which donor funds were pooled and prioritised.

The Security Sector Reform (SSR) process also placed key donors in charge of coordinating the international effort with regard to the reform of the Afghan army (US), police (Germany), disarmament and reintegration (Japan), justice (Italy) and counter-narcotics (UK). These 'lead nations', initially charged with coordinating international assistance with the newly formed Interim Administration and supporting the authorities in developing comprehensive strategies, soon acquired a growing responsibility for funding and implementing programmes in their particular area of Security Sector Reform.

Within the development architecture of sectoral assistance, NPP s, and SSR, there was less space for the kind of alternative development projects of the past. Many rural areas were decidedly more congested than they were in the 199os, with multiple agencies and initiatives operating in the same districts and communities, often regardless of whether opium poppy was cultivated or not. With large national sectoral programmes being designed and implemented and a multitude of national, international and non-governmental organisations working across rural Afghanistan, there were few areas that drug control organisations such as UNODC could set apart, call their own, and use to implement a range of different sectoral programmes tied to reductions in opium production. The policy of conditionality was also rejected in the initial years after the fall of the Taliban by most of the major donors, on the grounds that it would undermine efforts to build a social contract between the Afghan state and the rural population, one of the core objectives of the reconstruction effort. In fact, there was broad support for an approach that put reconstruction and development first, and situated the reduction in drug crop cultivation as an externality of the development process. 
Even those leading global counter-narcotics efforts within the US administration - who had long been advocates of aggressive eradication and dramatic reductions in drug crop cultivation in other parts of the worldinitially argued that the situation in Afghanistan was qualitatively different from that in other drug-producing nations. For example, Rand Beers, the then head of the US Department of State's Bureau of International Narcotics and Law Enforcement Affairs (INL), argued that the scale of cultivation within the country, the formidable challenges the population faced following the civil war, drought, the collapse of state institutions, and the amount of reconstruction and development assistance that was to be made available meant that responses to drug production in Afghanistan needed to be different from those in other source countries (Mansfield, 2016, 148). As such, until 2005, neither INL nor USAID pressed for rural development programmes specifically aimed at reducing opium poppy cultivation or for making development assistance contingent on reductions in poppy cultivation (SIGAR, 2018a, 107). Instead, the emphasis in these initial years was on designing a wide range of development interventions that would meet the immediate needs of the Afghan population and, in part, address the causes of opium poppy cultivation.

Indeed, the term 'alternative livelihoods' was established to signify change and to move away from the alternative development model that had been rejected by the development community in Afghanistan and more broadly (UNODC, 2015, 84 and 118) (see Table 5.1). This represented a break from an approach to development assistance that had — perhaps unfairly—become increasingly associated with crop substitution as well as with UNODC, an organisation whose development capacity was being questioned by many donors following its experience with ADCRRP and $\mathrm{C}_{2} 8$ in the 199os. The development funding available for Afghanistan far exceeded any of the alternative development programmes of the past and was beyond the capacity of a single agency to manage. For example, multilateral initiatives, such as the first phase of the National Solidarity Program (NSP) - a community-based rural development programme implemented between 2003 and 2007-cost USD 600 million. Bilateral programmes, such as the US government's Rebuilding Agricultural Markets Program (RAMP), had a budget of USD 143 million between 2003 and 2007. The development landscape of the post-Taliban era was fundamentally different from that of the 199os.

It was also recognised that there was no single project or programme that could address the multiple factors that led to the expansion of opium poppy cultivation in Afghanistan, and that a more concerted and comprehensive effort was required. Counter-narcotics had been made a cross-cutting issue under the Interim Afghanistan National Development Strategy (I-ANDS), 
TABLE 5.1 What are the differences between 'alternative development' and 'alternative livelihoods'?

\begin{tabular}{|c|c|c|}
\hline & Alternative development & Alternative livelihoods \\
\hline $\begin{array}{l}\text { Characteristic } \\
\text { feature }\end{array}$ & $\begin{array}{l}\text { Discrete, area-based project } \\
\text { approach }\end{array}$ & $\begin{array}{l}\text { Mainstreaming of counter- } \\
\text { narcotics objectives into } \\
\text { national development } \\
\text { strategy and programming }\end{array}$ \\
\hline $\begin{array}{l}\text { Problem } \\
\text { analysis }\end{array}$ & $\begin{array}{l}\text { Problem definition usually } \\
\text { limited to the presence of } \\
\text { illicit drug crops within a } \\
\text { specific area }\end{array}$ & $\begin{array}{l}\text { Analysis of the drivers of the } \\
\text { opium poppy economy }\end{array}$ \\
\hline Agenda & $\begin{array}{l}\text { Primarily reduction of illicit } \\
\text { drug crop cultivation and } \\
\text { treats the symptoms of } \\
\text { cultivation }\end{array}$ & $\begin{array}{l}\text { A wider state-building and } \\
\text { development agenda that } \\
\text { addresses the causes of } \\
\text { cultivation }\end{array}$ \\
\hline Actors & $\begin{array}{l}\text { Designed and implemented } \\
\text { by both national and } \\
\text { international drug control } \\
\text { organisations }\end{array}$ & $\begin{array}{l}\text { Designed and implemented } \\
\text { by development actors; } \\
\text { coordination and technical } \\
\text { support from drug control } \\
\text { bodies }\end{array}$ \\
\hline $\begin{array}{l}\text { Method of } \\
\text { implementation }\end{array}$ & $\begin{array}{l}\text { Attempts to replace on-farm } \\
\text { income generated by coca } \\
\text { and opium poppy }\end{array}$ & $\begin{array}{l}\text { Address the factors that } \\
\text { influence households' drug } \\
\text { crop cultivation }\end{array}$ \\
\hline $\begin{array}{l}\text { Impact } \\
\text { assessment }\end{array}$ & $\begin{array}{l}\text { Measured in reduction of } \\
\text { hectares of illicit drug crop } \\
\text { cultivation }\end{array}$ & $\begin{array}{l}\text { Measured in both human } \\
\text { development terms as well } \\
\text { as drug control indicators; } \\
\text { seeks to understand the } \\
\text { processes that influence } \\
\text { households in their } \\
\text { shift from illicit to licit } \\
\text { livelihoods }\end{array}$ \\
\hline Strengths & $\begin{array}{l}\text { Previously the only way of } \\
\text { delivering development } \\
\text { assistance to marginalised } \\
\text { illicit drug crop-producing } \\
\text { areas }\end{array}$ & $\begin{array}{l}\text { Recognises overlap between } \\
\text { development and drug } \\
\text { control agendas; part of } \\
\text { national development } \\
\text { strategy }\end{array}$ \\
\hline
\end{tabular}


TABLE 5.1 What are the differences between 'alternative development' and 'alternative livelihoods'? (cont.)

\begin{tabular}{|c|c|c|}
\hline & Alternative development & Alternative livelihoods \\
\hline Weaknesses & $\begin{array}{l}\text { - Poor understanding of } \\
\text { the process of change from } \\
\text { licit to illicit livelihoods; } \\
\text { often reduced to adoption of } \\
\text { "conditionality clause" } \\
\text { - Rarely linked to wider } \\
\text { national development } \\
\text { strategy } \\
\text { - Ignores broader role of } \\
\text { illicit drug crops } \\
\text { - Little consideration of key } \\
\text { development issues, poverty, } \\
\text { gender and environment }\end{array}$ & $\begin{array}{l}\text { - Danger of being reduced } \\
\text { to alternative income source } \\
\text { projects and ignoring the } \\
\text { broader institutional issues } \\
\text { - Complex to implement }\end{array}$ \\
\hline
\end{tabular}

SOURCE: MANSFIELD AND PAIN $(2005,4)$

and the National Drug Control Strategy (NDCs) of 2003 called for the mainstreaming of counter-narcotics policy in national and provincial plans and strategies (Government of the Islamic Republic of Afghanistan, 2003). Intimately linked with the concept of counter-narcotics mainstreaming, the intention of alternative livelihoods was to integrate efforts to address the causes of opium poppy cultivation in the wider policies and programmes of international, national and non-governmental organisations working in rural Afghanistan. This move was a recognition that the drugs issue in Afghanistan, as it is elsewhere, was a complex and 'wicked problem' where a 'whole-ofgovernment' approach was needed, not only by the Afghan government but also by the donors and particularly by the development institutions within Western governments that programmed much of the assistance being given to Afghanistan (Conklin, 2001).

There were periods when some of the largest development donors in Afghanistan engaged heavily in efforts to integrate an understanding of drug crop cultivation and the multifunctional role it played in rural livelihood strategies into broader development planning. The Asian Development Bank, the 
European Commission and the World Bank all pursued initiatives aimed at designing their programmes so that they could be more effective in addressing the causes of opium poppy cultivation. A number of NPP s were also appraised during design and implementation to ensure that they took better account of the fact that opiates were produced, traded and used in Afghanistan. These programmes were adjusted so that their activities might better address the causes or, at least, not make matters worse. This included programmes such as the National Emergency Rural Access Project (NERAP), the National Emergency Horticulture and Livestock Project (NEHLP) and the National Emergency Irrigation Rehabilitation Project (NEIRP).

The World Bank also developed a guideline note for Treating the Opium Problem in World Bank Operations in Afghanistan, or what became known as 'counter-narcotics mainstreaming guidelines'. DFID and the World Bank went further, producing a major report examining how development efforts might better address the causes of opium poppy cultivation (Ward et al., 2008). This report served as the justification for the design of the Comprehensive Agriculture and Rural Development -Facility (CARD-F), a rural development programme designed to identify and then support potential turnkey operations in rural areas of economic opportunity where opium poppy had been all but eliminated.

Ultimately, these efforts to recast and redefine how development actors should respond to opium poppy cultivation in Afghanistan were shaped by political events, and in particular the changing policy positions of the major donors, as well as the Afghan government itself. The perception of the 'statebuilding project' in Afghanistan and its close association with the amount of opium poppy cultivated were critical. With each rise in cultivation there was growing political pressure, particularly from the US government-and within it INL - for initiatives that would lower opium production and do so quickly. While the main thrust of this pressure was directed at increasing levels of eradication, in particular the push for the introduction of aerial spraying, it also impacted on rural development initiatives in poppy growing areas, especially the reintroduction of conditionality.

For example, in 2005, the US government launched a large bilateral Alternative Livelihoods Program in direct response to the rise in cultivation seen across Afghanistan the previous year. This programme consisted of projects in the east (USD 115.8 million), north (USD 50.9 million), and south (USD 166.4 million), with a subsequent extension into the south-west (USD 75.1 million) that ran until 2009 (SIGAR, 2018a, 112). So that the programme could be seen to be explicitly addressing opium poppy cultivation, projects called for farmers to 'voluntarily subscribe to the reduction of cultivation of poppy' and 
called for assistance to be halted where they failed to do so (USAID, 2009, 5). ${ }^{3}$ The same knee-jerk reaction - and attempt to tie development programming directly to poppy reduction - could be seen with the Helmand Food Zone (HFZ) in 2008. This was a UK and US government funded effort to drive down opium production in the face of the unprecedented level of opium poppy cultivation in Helmand that year and lasted until 2011. Consisting of three parallel prongs - wheat seed and fertiliser provision, an awareness campaign to deter planting, and eradication - this programme also required farmers to sign guarantees that they would not cultivate opium poppy. Conditionality was back (SIGAR, 2018a).

This was despite USAID's reticence to incorporate INL's efforts to make development assistance contingent on reductions in poppy cultivation (USAID, 2001). As an institution they had learned the challenges of linking aid directly to opium poppy cultivation in Afghanistan and other drug crop-producing countries (USAID, 2001). The guarantees signed by farmers under ADP were rarely enforced and the evaluation of the ALP-south questioned whether the project had any impact on poppy at all. The perceived success of the HFZwhere cultivation fell by 37 per cent in the short term from 103,00o hectares in 2008 to 63,000 hectares in 2011 (see Figure 5.1) — changed that. It also led to USAID being pressed by the Department of State and the US Ambassador at the time to launch a similar largely single sector, two-year programme in the neighbouring province of Kandahar in 2012, the Kandahar Food Zone ( $\mathrm{KFZ}$ ), where conditionality was once again applied (SIGAR, 2018a, 124).

Alongside these more short-term, single-sector programmes that were akin to the alternative development programmes of the 199os, USAID ran a range of large-scale rural development programmes, many of them partly funded from a Congressional budget for 'alternative development'. In contrast to programmes like $\mathrm{HFZ}$ and $\mathrm{KFZ}$, these programmes all but ignored opium production, fuelled by the belief that a growing legal rural economy would offer farmers an alternative and deter drug crop cultivation (USAIDAfghanistan, 2016).

3 For example, the draft notes of discussions of an Alternative Livelihoods Seminar on 3 September 2005 state 'Al Merkel from USAID added that USAID ALP had a two year "conditionality" clause in place in its programmes, which meant that if after two years there was no impact on poppy cultivation then assistance would be halted'. The workplan for RADP N also states that 'The requirement that farmers voluntarily subscribe to the reduction of cultivation of poppy is an important criteria for final selection of target areas' (USAID, 2006, 21). The project completion report for ADP North also refers to the fact that 'Conditionality may be imposed in the second year of project implementation' (USAID, 2009, 5). 


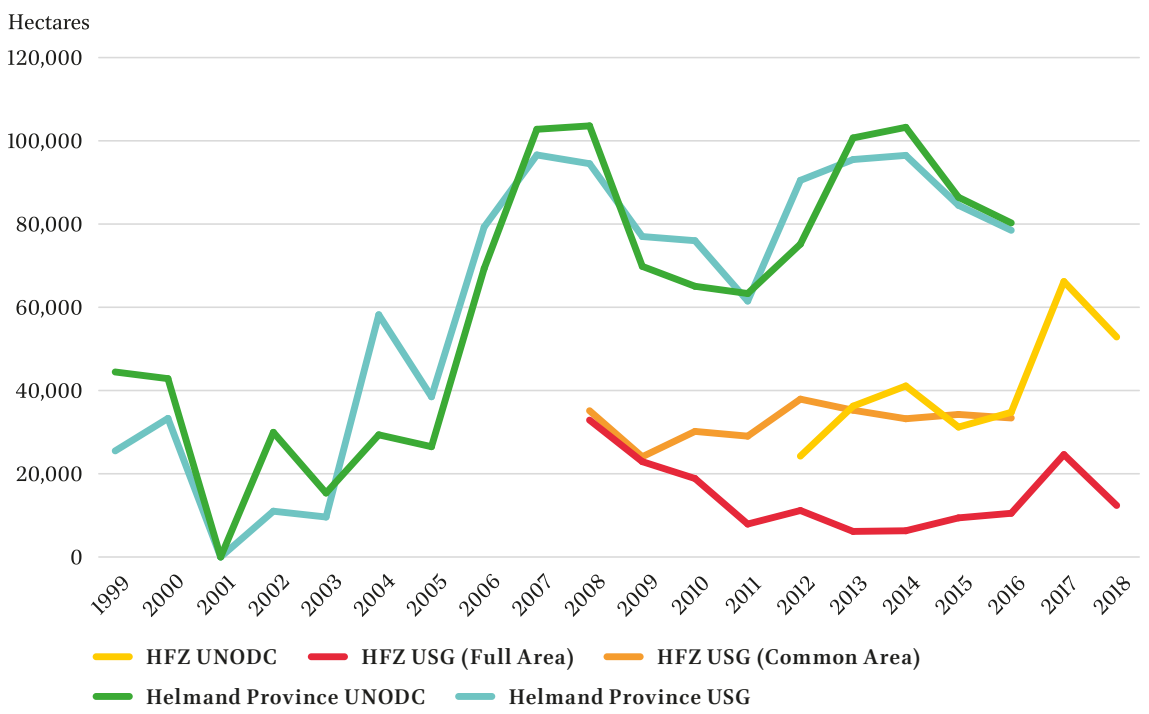

FIGURE 5.1 Opium poppy cultivation in Helmand, 1999-2018 (in hectares)

SOURCES: UNODC (2019); CNC AND UNITED STATES GOVERNMENT (2019)

The scale of this assistance was impressive. So much so that by 2018 the US government had spent USD 1.46 billion on what it termed alternative development, the vast bulk of which was rural development programmes in poppy growing areas that made little direct reference to opium poppy in their design, implementation or subsequent evaluations (SIGAR, 2018a, 118). These included projects such as the Accelerated Sustainable Agriculture Program (2006-10) at a cost of USD 132.6 million, the Community Development Program, West, East, South and Kabul (2009-12) with a total budget of USD 334 million, the Afghanistan Vouchers for Increased Production in Afghanistan (2008-13), costing USD 323 million, and the Commercial Horticulture and Agriculture Program (2010-19) at a cost of USD 71 million.

All of these projects were funded from the US government's alternative development budget line, and operated in poppy growing areas in Afghanistan but did not offer any indication of how the interventions they delivered would support farmers' transition out of opium poppy cultivation (SIGAR, 2018a, 118-119). As USAID/Afghanistan itself concluded:

USAID's general approach with respect to [alternative development] funding, therefore, has been to assume that investments to increase high value crop production would, as a matter of course, discourage poppy production. However, there has been little effort given to examining the 
impact of our programs on poppy cultivation, or as importantly, the impact of poppy production on the implementation of USAID programs. This has left USAID's [alternative development] efforts relatively diffused and unfocused, and, it is argued, led to marginal or unsustainable impacts on poppy cultivation.

USAID/Afghanistan, 2014, 4

In the absence of any mandatory requirement by the Afghan government or their own governments to incorporate interventions that would deter opium poppy cultivation, other development donors adopted the same position. In fact, by 2009, counter-narcotics had fallen off the wider political agenda, in part displaced by the growing insurgency and the challenges of the presidential elections, but also by reductions in opium poppy cultivation overall. Development donors welcomed the opportunity to delegate all responsibility for reducing opium poppy cultivation to law enforcement, and to USAID and other donors that supported initiatives such as the $\mathrm{HFZ}$ and $\mathrm{KFZ}$, while they focused on supporting economic growth.

The challenge with many of these development programmes was not that they did not explicitly tie themselves to the objective of reducing opium poppy cultivation - this was beyond their legal mandate and ability to deliver, and few other than UNODC thought that applying conditionality across all development assistance would deliver on either development or drug control objectives. The issue was more that they did not look at how they might best contribute to reducing farmers' dependence on opium as a livelihood strategy, or-more importantly-ensure that they did not make matters worse.

The result was that some of these interventions, like that of the HFZ and KFZ, inadvertently encouraged opium poppy cultivation. For example, fertiliser was diverted to opium production, and improved irrigation led to more land falling under higher yielding opium poppy. Less direct effects could be seen from conventional rural development programmes that focused on increasing wheat production, such as the Regional Area Development Programs (RADP) that USAID launched at the cost of USD 300 million (SIGAR, 2018a). These risked (i) displacing the land-poor, who had relied on the labour-intensive opium crop to gain access to land as a sharecropper, including to former desert areas where they would cultivate even more poppy, as had been done under the HFZ, and (ii) improving wheat yields, so that more land was available for high value crops, including opium poppy. Other programmes, such as the extension of high value horticulture, could also lead to those that sharecropped land finding themselves without a home, land, and access to food crops, leading to them 
uprooting their families and looking for land elsewhere where they could grow opium poppy.

In sum, while there were understandable reservations regarding the adoption of a crude and counterproductive conditionality as a means of being seen to be explicitly addressing opium poppy cultivation, ignoring the fact that opium poppy was grown in an area was not an option. Turning a blind eye to such cultivation could, in fact, encourage further cultivation, as well as displace and marginalise the poor, rendering development programmes ineffective in fulfilling their pro-poor mandates and making matters worse with regard to illicit drug crop cultivation.

\section{5}

Alternative Development: Resistance to Change

By 2018, the clock appeared to have been turned back all the way to the 199os. USAID was no longer involved in any development programming with links to opium poppy cultivation (SIGAR, 2018b, 189). Other donors, such as the World Bank, ADB, and EC, also ignored opium poppy cultivation even where they were funding large-scale irrigation programmes in poppy growing areas (World Bank, 2014, 41; Byrd and Mansfield, 2014). INL and UNODC were once again in the driving seat, pressing for short-term alternative development programmes that made assistance contingent on reductions in poppy cultivation.

Attempts to reshape the debate on counter-narcotics and alternative development in Afghanistan failed. Despite a number of efforts by those donors most involved in rural livelihoods programmes to better integrate drugs into development programmes, they made little progress with implementation. The reasons for this were manifold and were largely political and technical, in addition to the ubiquitous challenge of maintaining a quorum of interested donors given the rapid staff turnover in Kabul.

As Conklin (2001) defines it, the drugs issue in Afghanistan is a complex, 'wicked problem', one that required cross-government support and ownership, not just within the Afghan government but also among Western donor nations. This was not achieved. Then Afghan President Hamid Karzai showed little interest in the subject and, despite the UK's lead nation' and then 'partner nation' role, successive UK prime ministers failed to understand fully what was required. What is more, neither the political leadership in Afghanistan nor that among the Western allies had a common and consistent understanding of the drugs issue or how it related to the wider 'Afghan project' in its various forms - counterterrorism, state building or counter-insurgency. Those institutions charged with the responsibility to deliver on counter-narcotics—such as 
the UK Afghan Drugs and Inter-Departmental Unit (ADIDU) and the INL — did not control all the levers, nor did they always have the technical capacity to engage constructively with those institutions responsible for delivering security, governance and economic growth.

Set up as a parallel strand of institutions and activities, they found themselves in a state of constant competition for resources and the attention of senior political leaders, who did not always see the relevance of the drugs issue to the wider mission and lacked a common understanding of how best to manage the negative consequences of widespread opium production. Moreover, the drug control community was often seen as pursuing short-term drug control targets-specifically, dramatic reductions in annual levels of opium poppy cultivation - that were often viewed by members of the development, diplomatic and security communities as detrimental to their institutional objectives.

Within the development community itself, there were major challenges building ownership over the drugs issue in Afghanistan. This was particularly the case for senior officials in Afghan development ministries and Western donors. Both preferred to see the drugs issue as one for someone else to deal with - typically, the growing drug control community that inhabited institutions such as the Afghan Ministry of Counter Narcotics (previously the Counter Narcotics Directorate); INL; the British Embassy Drugs Team (BEDT); and law enforcement organisations within the Afghan Ministry of Interior and the international community, such as the US Drug Enforcement Administration (DEA) and the UK's Serious Organised Crime Agency (sOCA).

Western development donors' senior managers were particularly resistant to engaging on the drugs issue. Although technocrats in Kabul responsible for programmes promoting development in rural Afghanistan would rarely countenance designing or funding an intervention that ignored the country's most valuable export, many senior officials in other capitals did not want to see their organisation engage on counter-narcotics, fearing they would be held responsible for any subsequent fluctuations in opium poppy cultivation. They were of the view that no good would come of being part of what might be perceived as a counter-narcotics mandate and would argue that doing so would run contrary to the pro-poor development objectives of their institution. Afghan leadership would typically follow this lead, absent pressure to engage from their main development donors.

Another obstacle, particularly in the formative years of the Western allies' intervention in Afghanistan, was the largely bilateral strategy of USAID described in the previous section. The scale of the US development budget and its focus on implementing bilateral 'alternative development' programmes 
through contractors meant that it could largely pursue its own agenda, separate from that of the other major donors. Thus, while some of the largest development donors involved in rural development would meet to discuss how to better integrate the drugs issue into their development plans, and even pursue joint initiatives between 2005 and 2009, USAID often was absent from the discussions. Instead, it pursued large bilateral programmes, some of which were described as alternative development and others as rural development, often with no clarity as to what differentiated one from the other (SIGAR, 2018b, 128).

The absence of USAID from donor discussions, as well as the perception that it persisted with a set of distinct alternative livelihoods/development projects, did not match the messages that technocrats in Kabul were presenting to the Afghan development ministries. The continuation of a type of 'alternative development' akin to that of the 199os reinforced the tendency of senior managers in Western donors to look for bounded development projects that they could label as 'counter-narcotics'. This seemingly allowed senior managers to respond to political pressure within their own governments and engage in counter-narcotics, while maintaining a strategic distance-they did not have to integrate drugs into their wider portfolio of development programmes and policy dialogue in Afghanistan.

A further constraint preventing the integration of drugs into wider development was the planning process itself. Designed mostly from Kabul, development programmes were rather generic, identifying the provinces and districts that they would work in with only little detail. They lacked specifics on the context of particular areas, the resource endowments and the complex and diverse nature of the rural livelihood strategies pursued by the local population. This was all to be worked out during the implementation of individual NPP s or bilateral programmes. Efforts to build synergies between these different, centrally designed programmes at the local, district and provincial level were often hampered. The National Solidarity Program (NSP) was intended to establish local mechanisms for development planning in the form of Community Development Councils (CDC s), but some ministries and programmes were reluctant to work through them. Attempts to build provincial development plans under the National Area-Based Development Program (NABDP) also faltered. This led to the counter-narcotics community developing provincial counter-narcotics plans for a number of key provinces through the technical support it provided to the Ministry of Counter Narcotics. Due to a heavy focus on counter-narcotics and the failure to gain traction in the wider development community—which held the purse strings—-this initiative proved unsuccessful. 
Related to the problem of coherent provincial- and district-level development plans was the issue of technical capacity. Integrating the causes of opium poppy cultivation into rural development interventions, understanding how the reasons for cultivation differ by socio-economic group, and designing interventions that, at best, would reduce the dependency on opium as a livelihood strategy and, at least, would not make matters worse required a deep knowledge of rural Afghanistan (Ward et al., 2008). This was knowledge that many donors and the contractors that implemented their programmesincluding those that provided technical assistance to Afghan development ministries - did not possess. Although this lack of knowledge became a consequence of the deteriorating security conditions and the stringent duty of care that Western donors imposed upon their staff, it was also a function of the high staff turnover that had beleaguered the Afghan reconstruction effort since its start.

In the absence of knowledge about rural Afghanistan, the default scenario for development organisations was to assume that an intervention that promotes growth in the legal economy would lead to a contraction in the opium economy. The USAID bilateral funding programme was littered with programmes that followed just such a lead, including the RADP s for South (USD 125.1 million), North (USD 78.4 million), West (USD 69.9 million) and East (USD 28.1 million) (SIGAR, 2018b, 120), as well as the Commercial Horticulture and Agricultural Marketing Program (USD 71 million) (SIGAR, 2019b, 178) and more recently the Value Chain Programs for Livestock (USD 55.6 million), High Value Crops (USD 54.9 million) and West (USD 19 million) (SIGAR, 2019b, 178). Criticised by USAID's own Inspector General (USAID, 2012, 5), this approach rested on a false assumption in the case of the programme Incentives Driving Economic Alternatives-North East West (USD 16o million) in the province of Nangarhar (Mansfield, 2015a).

Afghanistan is inundated with a variety of programmes that highlight the consequence of failing to adequately consider the impact of their activities on opium poppy cultivation. There are numerous examples of the deleterious effects of poorly planned and implemented programmes. These include the $\mathrm{HFZ}$, which ignored the likely effects encouraging widespread wheat cultivation would have on different population groups, thereby marginalising the land-poor and driving them into the former desert areas of Helmand where they cultivated more poppy, and rural development programmes that provided inputs like irrigation and fertiliser that were subsequently diverted to produce higher opium yields (see Figure 5.2) (Mansfield, $2015 \mathrm{~b}$ ). What is perhaps most surprising is how little has been learned since the 199os. 


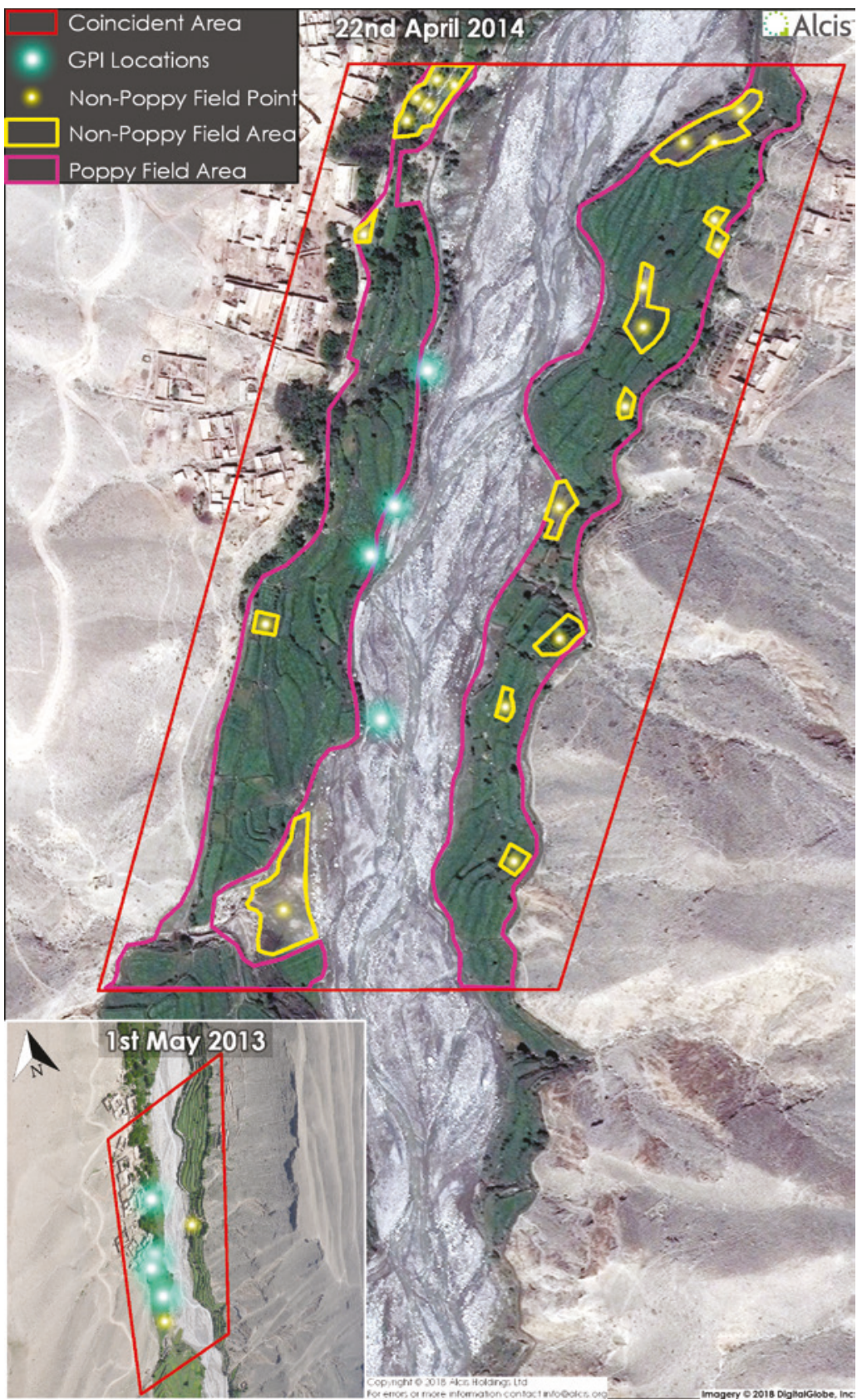

FIGURE 5.2 Irrigation project funded by the Good Performance Initiative being used to grow more opium poppy in Pachir Wa Agam, Nangarhar SOURCE: ALCIS (2018), CITED IN SIGAR (2018B) 
In Afghanistan, alternative development has reverted to the default of the 199os. Misused and misunderstood, the term came to mean all things to all people during the post 2001 reconstruction. Initial development efforts that drew on the failures of alternative development in the 199os looked to avoid both initialising area-bound interventions of the past, and making assistance contingent on reductions in opium poppy cultivation. Instead, they looked to integrate the causes of drug crop cultivation into the design and implementation of rural development programmes, including the NPP s.

However, ultimately, the lack of senior political leadership, the inconsistent and insufficient ownership of the drugs issue among the development community, centralised and disparate development planning processes, and limited technical capacity resulted in intermittent and inconsistent engagement by development organisations on the issue in Afghanistan.

Periods of peak engagement were often when levels of opium poppy cultivation increased nationally or in a particular province, especially one where a Western government led the Provincial Reconstruction Team, and development staff would find themselves compelled to engage directly in counternarcotics efforts. This was largely driven by the perception that rising levels of cultivation reflected a failure in the state-building project in Afghanistan or, worse still, represented poor performance of a Western nation's military and civilian effort within the province where cultivation was increasing. When levels of cultivation were static or falling, there would be no such pressure, and senior development officials would even dissuade their staff from engaging in the drugs issue at all — even when programmes they were funding were providing assistance in areas where opium production was concentrated.

In the absence of a more consistent and meaningful engagement on the drugs issue by a quorum of development donors and Afghan ministries, the drug control community filled the gap. In fact, it is fair to say that the default position has typically been one where institutions such as UNODC, the Afghan Ministry of Counter Narcotics and INL have pushed what they perceive as a development model in drug growing areas, repeating calls for conditionality or a 'social compact' that tied aid to reductions in opium poppy cultivation (Costa, 2002; UNODC, 2016). Over time, alternative livelihoods came to be seen as synonymous with alternative development, and in some areas-most notably with the provision of wheat seed in Helmand under the Food Zone initiative-even began to look like crop substitution, an approach that even the drug control community had abandoned in the 1980s. 
The reality is that a simplistic understanding of alternative development where it is linked to conditionality, and what appears to be a crude exchange of development inputs for a commitment to reduce drug crop cultivation, retains a certain attraction, particularly for senior political leadership. First, tying development assistance directly to reductions in cultivation infers causality between development inputs and drug control outcomes, even where evidence in rural Afghanistan has shown that it does not exist. Second, it provides an optic of specificity between an investment of funds and reductions in cultivation that development specialists can rarely offer, particularly given the weakness in the monitoring and evaluation mechanisms of the development community in Afghanistan and the reliance on attitudinal surveys, such as those deployed in Helmand. ${ }^{4}$

Finally, perhaps the most valuable aspect of this idea of 'exchange' is that it provides a political target for subsequent recriminations when reductions in opium poppy cultivation do not occur or when they are not sustained. Once cultivation fails to fall or there is a resurgence, it is easy to blame the national leadership, provincial governors, district officials or even community leaders for their 'lack of commitment' to drug control, their cynicism in taking development monies and not living up to their side of the bargain, and perhaps even their corruption and involvement in the drug trade. Although many of these claims may be true in part, conditionality fundamentally continues to fail to reflect the decentralised and contested nature of political power in rural Afghanistan. The reality is that those in positions of power would not have the capacity to retain that power if they were to impose prolonged periods of hardship on large sections of the rural population.

Without recourse to the kind of coercive capacity required to enforce conditionality, those looking for reductions in drug crop cultivation in Afghanistan have to work at a different pace and with unfamiliar instruments. Reaching a common understanding with the development community as to how improved

4 Examples include the Helmand Monitoring and Evaluation Program (hMEP), a UK funded initiative used to assess the impact of stablisation efforts in Helmand. The polling conducted by HMEP was subject to significant bias. For example, HMEP reported that only $3-5$ per cent of households in Helmand earned a revenue from opium in 2013 despite the scale of cultivation in the province, which had risen from 75,176 hectares to 100,693 hectares between 2012 and 2013 , with some areas cultivating as much as 62.5 percent of agricultural land. Other surveys showed the same systematic underreporting of opium poppy cultivation, including large-scale ones such as the National Risk and Vulnerability Assessment (NRVA), and more limited ones such as those carried out by Incentives Driving Economic Alternatives-North, East, West (IDEA-NEW) and Measuring Impact of Stabilization Initiatives (MISTI) (see Mansfield, 2015a, 8). 
welfare, social protection and economic growth can address the causes of opium poppy cultivation and reduce dependency on drug crops as a livelihood strategy would help. Working with development donors and ministries to ensure that current and pipeline programmes do not lead to growing levels of cultivation or to the population's increasing dependency on opium production as a livelihood strategy would also prove to be an invaluable exercise. It is without question in Afghanistan that exorcising the term alternative developmentand its association with bounded and conditional development assistancewould also aid both the debate on what to do about illicit drug crops, but also that on the role that the wider development community can play.

\section{References}

Afghanaid (1989) Opium Crop Substitution Programme, Achin District, Nangarhar, Evaluation Report (Kabul: Afghanaid).

Byrd, W. and D. Mansfield (2014) Afghanistan's Opium Economy: An Agriculture, Livelihoods and Governance Perspective, SASPR Working Paper Series, Agriculture Sector Review (Kabul: World Bank Afghanistan) http://siteresources.worldbank.org/ INTAFGHANISTAN/Publications-Resources/2032506o/AFOpium-Drug-EconomyWP.pdf.pdf (accessed on 23 April 2020).

CNC (Crime and Narcotics Centre) and United States Government (2019) Afghanistan poppy cultivation and opium production by province, Unpublished Report.

Conklin, J. (2001) Wicked Problems and Social Complexity (Napa, California: CogNexus Institute), https://cognexus.org/wpf/wickedproblems.pdf (accessed on 23 April 2020).

Costa, A.M. (2002) Statement by Antonio Maria Costa, Director General United Nations Office Vienna and Executive Director of United Nations Office for Drug Control and Crime Prevention, Coordination Conference on Drugs_-Kabul, 23 July (Kabul: UNODC), https://www.unodc.org/unodc/en/about-unodc/speeches/speech_2002-0723_1.html (accessed on 26 April 2020).

Gelbert, R. (2000) An Assessment of Social Impact and Community Development, Unpublished Report.

Government of the Islamic Republic of Afghanistan, Counternarcotics Directorate (2003) Afghanistan Counternarcotics Strategy (Kabul: Counternarcotics Directorate).

Kapila, M., G. Templar and E. Winter (1995) Review of British Aid to Afghanistan, Emergency Aid Department, Western Asia Department (London: Overseas Development Administration). 
Mackrell, D. (1999) A Review of Strategy in Shinwar District, UndCP Afghanistan Programme, Unpublished Report.

Mansfield, D. (2016) A State Built on Sand: How Opium Undermined Afghanistan (London: Hurst Publishers).

Mansfield, D. (2015a) Effective Monitoring and Evaluation in Conflict Affected Environments: Afghanistan Post -2014, Peaceworks, 112 (Washington, D.C.: United States Institute for Peace, USIP).

Mansfield, D. (2015b) Examining the Impact of IDEA-NEW on Opium Production: Nangarhar-A Case Study (Washington, D.C.: USAID).

Mansfield, D. (2015c) Helmand on the Move: Migration as a response to Crop Failure, AREU Briefing Note, October (Kabul: Afghanistan Research and Evaluation Unit, AREU), https://www.refworld.org/pdfid/562095fe4.pdf (accessed on 24 April 2020).

Mansfield, D. (2004) Conditionality and its effectiveness in Afghanistan: A discussion paper, unpublished discussion paper for the CND/UNODC Workshop on Conditionality and Mainstreaming (Vienna, Austria).

Mansfield, D. (2001) Alternative Development in Afghanistan: The Failure of Quid Pro Quo, unpublished paper produced for Deutsche Gesellschaft für Internationale Zusammenarbeit (GIZ).

Mansfield, D. and A. Pain (2005) Alternative Livelihoods: Substance or Slogan? AREU Briefing Paper (Kabul: AREU).

SIGAR (Special Inspector General for Afghanistan Reconstruction) (2019a) Quarterly Report to the United States Congress, October (Arlington: SIGAR), https://www.sigar. $\mathrm{mil} / \mathrm{pdf} /$ quarterlyreports/2019-10-30qr.pdf (accessed on 24 April 2020).

SIGAR (2019b) Quarterly Report to the United States Congress, July (Arlington: SIGAR), https://www.sigar.mil/pdf/quarterlyreports/2019-07-3oqr.pdf (accessed on 26 April 2O2O).

SIGAR (2018a) Counternarcotics: Lessons from the US Experience in Afghanistan, June (Arlington: SIGAR) https://www.sigar.mil/interactive-reports/counternarcotics/index.html (accessed on 26 April 2020).

SIGAR (2018b) Quarterly Report to the Unites States Congress, April (Arlington: SIGA), https://www.sigar.mil/pdf/quarterlyreports/2018-o4-3oqr.pdf (accessed on 26 April 2020).

Sloane, P. (2000) Project Impact Report: Impact Assessment of Project $C_{2} 8$, Unpublished Report.

UNDCP (United Nations Drug Control Programme) (1997) Afghanistan Programme Appraisal Mission-Aide Memoire, November (Islamabad: UNDCP).

UNDCP (1996) Programme Concept Note (Islamabad: UNDCP).

UNDCP (1995a) Assessment Strategy and Programming Mission to Afghanistan (Vienna: UNDCP).

UNDCP (1995b) Briefing Note on Afghanistan, Unpublished Memo (Islamabad: UnDCP). 
UNODC (United Nations Office on Drugs and Crime) (2019) Afghanistan Opium Survey 2019, Executive Summary (Vienna: UNODC).

UNOdC (2016), UNODC Sub Program 3-Alternative Development, INL Proposal, Strengthen and Diversify Licit Livelihoods through Alternative Development Interventions - September 2016-August 2020 (Kabul: UNODC).

UnODC (2015) World Drug Report 2015 (Vienna: UnODC), https://www.unodc.org/documents/wdr2015/World_Drug_Report_2015.pdf (accessed 23 April 2020).

UNODC (2009) Final Evaluation Report, Project Number $A F G / G 76$, Alternative Livelihoods, Capacity Building at National and Regional Level, Afghanistan (March), (Vienna: UNOC), https://www.unodc.org/documents/evaluation/ProEvals-20og/ afgg76_final_evaluation_report_rev.pdf (accessed on 26 April 2020).

USAID (United States Agency for International Development) (2012), Audit Report No. F-306-12-004-P, Office of Inspector General Audit of USAID/Afghanistan's Incentives Driving Economic Alternatives for the North, East and West Program (Kabul: USAID OIG).

USAID (2009) Alternative Development Program for Northeastern Afghanistan $(A D P / N)$, Project Completion Report, (Kabul: USAID OIG), https://documents. pub/document/alternative-development-program-for-northeast-afghanistanpdfusaidgovpdfdocs.html (accessed on 23 April 2020).

USAID (2006) Alternative Livelihoods Program Northern Region-Badakhshan and Takhar, Annual Workplan June 20o6-July 2007 (Kabul: USAID OIG).

USAID (2001) Information Memorandum, Lessons from Drug Crop Elimination, from Michael Deal to the Administrator, Unpublished Report.

USAID/Afghanistan (2016) Agricultural Assistance Strategy, Annex 5 (Kabul: UsAID OIG).

USAID/Afghanistan (2014) Agricultural Sector Assistance Strategy, Annex 5: Poppy Cultivation and USAID Alternative Development Efforts in Afghanistan (Kabul: USAID OIG).

Ward, C., D. Mansfield, P. Oldham and W. Byrd (2008) Afghanistan-Economic Incentives and Development Initiatives to Reduce Opium Production, Report 42401 (Washington D.C.: World Bank and Department for International Development), http://documents.worldbank.org/curated/en/992981467996725814/AfghanistanEconomic-incentives-and-development-initiatives-to-reduce-opium-production (accessed on 26 April 2020).

World Bank (2014) Islamic Republic of Afghanistan Agricultural Sector Review: Revitalizing Agriculture for Economic Growth, Job Creation and Food Security (Washington D.C.: World Bank), http://hdl.handle.net/10986/21733 (accessed on 24 April 2020). 